\title{
Estimation of Serum Hyaluronidase Activity Overcoming the Turbidity Interference
}

\author{
SHIVAIAH NAGARAJU, K SUBBAIAH GIRISH, YI PAN, \\ KIRK A EASELY, KEMPAIAH KEMPARAJU
}

\begin{abstract}
The assay of mammalian hyaluronidases (HAases) is important in understanding the role of the hyaluronan-hyaluronidase (HA-HAase) system in various pathophysiological processes. Despite several quantitative assay method options, the Morgan-Elson colorimetric method modified by Reissig et al [1] is considered the best for determining the activity in clinical samples. However, the sensitivity of the method was greatly limited by presence of protein above $400 \mu \mathrm{g}$ due to turbidity interference that led to chromogen quenching. Therefore, an effort has been made to reinvestigate the Reissig et al method. In the reinvestigated method, a standardized optimal $0.32 \mathrm{M}$ potassium tetraborate (PTB) was used against $0.13 \mathrm{M}$ (native) to overcome the turbidity interference. The estimated mean OD at $585 \mathrm{~nm}$ of serum for native method was 0.043 (95\% CI: 0.040 to 0.045 ), while that for the re-investigated method was 0.138 (95\% CI: 0.133 to $0.143, \mathrm{p}<0.0001)$. The mean $\mathrm{OD}$ at $585 \mathrm{~nm}$ of serum of native method was significantly lower than that of re-investigated method $(\mathrm{p}<0.05)$ at all protein levels. This was also true for estimated mean OD at 585 $\mathrm{nm}$ of plasma. The mean intrasample CVs for native and re-investigated methods were $0.9 \%$ and $0.5 \%$, respectively, for normal serum. Furthermore, the repeatability coefficient of normal serum for native was $0.003 \mathrm{IU}$, while re-investigated method experienced that of $0.002 \mathrm{IU}$.
\end{abstract}

INDEX TERMS: Hyaluronidase; Hyaluronan; Human serum; Colorimetric method; Turbidity interference

Clin Lab Sci 2011;24(3):172

Shivaiah Nagaraju, MSc., PhD, Department of Medicine, Division of Immunology and Rheumatology,
Stanford University, Stanford, CA, USA, Department of $P G$ Studies and Research in Biochemistry, Tumkur University, Tumkur

K Subbaiah Girish, MSc., PhD, Department of Biochemistry, University of Mysore, Manasagangothri, Mysore, Karnataka State, India

Yi Pan, MS, PhD Department of Biostatistics and Bioinformatics, Rollins School of Public Health, Emory University, Atlanta, GA

Kirk A Easely, MS, Department of Biostatistics and Bioinformatics, Rollins School of Public Health, Emory University, Atlanta, GA

Kempaiah Kemparaju, MSc., PhD, Department of Biochemistry, University of Mysore, Manasagangothri, Mysore, Karnataka State, India

Address for Correspondence: Dr. K. Kemparaju, Department of Biochemistry, University of Mysore, Manasagangothri, Mysore-570 006, India, +994599 6543,nagarajubiochem@gmail.com

\section{INTRODUCTION}

Hyaluronic acid (HA) is a high molecular weight nonsulfated glycosaminoglycan composed of repeating disaccharide unit of D-glucuronic acid (Glc UA) and $N$-acetyl-D-glucosamine (NAG). The HA is recognized as a major participant in important biological processes as cell motility, proliferation, differentiation and migration. The HA degrading enzymes, the HAases are found in various human organs and body fluids and in the external secretions of various other organisms. ${ }^{2-5}$ There are three groups of HAases according to their HA 


\section{RESEARCH AND REPORTS}

degradation mechanisms namely, ${ }^{1}$ hyaluronate 4glycanohydrolase (hyaluronoglucosaminidase: EC 3.2.1.35), ${ }^{2}$ hyaluronate 3-glycanohydrolase (hyaluronoglucuronidase: EC 3.2.1.36), and (3) hyaluronate lyase (EC 4.2.2.1). ${ }^{6}$ The HAases present in various mammalian tissues belong to the first group of enzymes and are of particular clinical interest as they have been demonstrated to be involved in the pathophysiology of many human disorders..$^{2-11}$ Due to their physiological importance, a rapid and sensitive method to measure HAase activity has become increasingly necessary. A variety of assay methods have been used to measure HAase activity, i.e., turbidometric, viscometric, and colorimetric methods, and newer methods such as spectrophotometric, fluorogenic, radiometric, agarose plate based, ELISAlike, HPLC, zymography, capillary electrophoresis, FACE- based and ECL-assisted assays. ${ }^{2,12-14}$

Despite several quantitative assay methods available, the Morgan-Elson colorimetric method modified by Reissig et $\mathrm{al}^{1}$ is considered to be the best and widely used method to determine the HAase activity in clinical samples including serum, plasma, saliva, urine and other body fluids. In the Morgan-Elson reaction the NAG in the reducing end is successfully transformed into a chromogen under alkaline condition at $100^{\circ} \mathrm{C}$ and subsequently by the action of $p$-dimethyl amino benzaldehyde ( $p$-DMAB) in glacial acetic acid and hydrochloric acid mixture $(9: 1 ; \mathrm{v} / \mathrm{v})$ to give a reddish purple colored product that can be detected at $585 \mathrm{~nm}$. However, this method is limited by the interference of variation in the $\mathrm{pH}$ of the sample; presence of other sugars, amino acids and $\mathrm{Mg}^{+2}$ and also the final color development often require 90 minutes. Reissig et $\mathrm{al}^{1}$ improved this method by substituting a concentrated PTB reagent $(0.8 \mathrm{M}, \mathrm{pH} 9.1 ; 50 \mu \mathrm{l} /$ assay volume of $300 \mu \mathrm{l}$, to a final concentration of $0.13 \mathrm{M} \mathrm{PTB}$ in the reaction mixture) for the original carbonate buffer. As a result of modification, the final color development required just 20 minutes and about 2 folds increase in the color yield. In spite of the significant improvement, the estimation of HAase activity in clinical samples such as serum, plasma and other body fluids was not satisfactory as there was a massive interference by turbidity upon increasing the protein concentration above $400 \mu \mathrm{g}$ in the reaction mixture. While, less than
$400 \mu \mathrm{g}$ of protein in the reaction mixture did not cause any turbidity. Hence, removal of turbidity in cases when excess of protein used was only through centrifugation at a high centrifugal force of about $18,000 x$ g. Although, the adoption of the curvilinear interpolation by Asteriou et al. ${ }^{15}$ overcomes the turbidity interference, this approach was not suitable especially for the assays of HAases performed at acidic $\mathrm{pH}$, since the resulting turbidity colored reaction mixture was often unstably suspended. Hence, balancing the protein content of the assay in order to get the measurable activity and at the same time preventing the turbidity formation is a critical practical difficulty. Therefore, it is highly unlikely to pick up the HAase activity can be picked up in cases of lesser protein levels $(<400 \mu \mathrm{g}$ protein) or results in turbidity in cases of higher protein levels ( $>400 \mu \mathrm{g}$ protein) in specimens turbidity would cause anomalous results. However, use of larger concentrations of the clinical sample (protein content $>400 \mu \mathrm{g}$ ) is quite essential to get the measurable activity. Therefore, considering these limitations, we attempted to re-investigate the Reissig et al. ${ }^{1}$ method by using an optimal concentration of PTB reagent $(2 \mathrm{M}, \mathrm{pH} 9.1 ; 50 \mu \mathrm{l} /$ assay volume of $300 \mu \mathrm{l}$, to a final concentration of $0.33 \mathrm{M} \mathrm{PTB}$ in the reaction mixture) to drastically reduce turbidity.

\section{MATERIALS AND METHODS}

Healthy donors (20-25 yrs age group), osteoarthritic and diabetic patients were recruited with informed consent according to the Declaration of Helsinki and as per University of Mysore institutional review board protocols to donate up to $5 \mathrm{ml}$ of whole blood. Hyaluronic acid (HA) and $N$-acetyl glucosamine were purchased from Sigma Chemicals Co. St Louis, USA. All other chemicals used were of analytical grade.

\section{Determination of hyaluronidase activity}

Hyaluronidase activity was determined according to the native method of Reissig et al (1955) and reinvestigated Reissig et al method.

Reissig et al method: Enzyme was incubated with HA $(50 \mu \mathrm{g})$ in a final reaction volume of $300 \mu \mathrm{l}$ of $0.1 \mathrm{M}$ sodium formate buffer ( $\mathrm{pH}$ 3.8) containing $300 \mathrm{mM}$ $\mathrm{NaCl}$ and incubated for $150 \mathrm{~min}$ at $37^{\circ} \mathrm{C}$. The reaction was stopped by adding potassium tetraborate, $(0.8 \mathrm{M}$, 


\section{RESEARCH AND REPORTS}

$\mathrm{pH}$ 9.1, $50 \mu \mathrm{l} /$ assay volume of $300 \mu \mathrm{l}$ to a final concentration of $0.13 \mathrm{M}$ ). The reaction mixture was kept in boiling water bath for exactly $3 \mathrm{~min}$. The coloring reagent $p$-dimethyl amino benzaldehyde $(p$ DMAB) in glacial acetic acid and hydrochloric acid (1.5 $\mathrm{ml}, 9: 1, \mathrm{v} / \mathrm{v}$ ) was added to give a reddish purple colored product that can be detected at $585 \mathrm{~nm}$. The change in absorbance was monitored at $585 \mathrm{~nm}$. Activity was expressed as $\mu$ moles of $\mathrm{N}$-acetyl glucosamine released $/ \mathrm{min} / \mathrm{mg}$ protein.

In reinvestigated method: To stop the reaction, $2 \mathrm{M}$ potassium tetraborate $(\mathrm{pH} 9.1 ; 50 \mu \mathrm{l} /$ assay volume of $300 \mu \mathrm{l}$, to a final concentration of $0.33 \mathrm{M} \mathrm{PTB}$ in the reaction mixture) was used instead of $0.8 \mathrm{M}$.

The primary endpoint (OD at $585 \mathrm{~nm}$; NAG estimation), was measured using both native and reinvestigated methods at different protein levels 0, 500, 1000, 1500 and $2000 \mu \mathrm{g}$. Repeated-measures analyses for OD was done with a means model with SAS Proc Mixed (version 9.2, mixed linear models). The repeated-measures analyses were done separately for the plasma and serum samples. A heterogeneous compound symmetry variance-covariance form among the repeated measurements was assumed for each outcome, and robust estimates of the standard errors of parameters were used to do statistical tests and construct 95\% confidence intervals. $\mathrm{T}$ tests were used to compare the pairwise differences between the model-based means (least squares means) at each protein level, providing separates of the means by method (native or reinvestigated) and protein level.

\section{Statistical analysis:}

Native and re-investigated methods were used to evaluate the enzyme activity of normal serum on the same 25 subjects. Each sample was measured three times by each method. Similar studies were performed for 25 diabetic samples and osteoarthritis samples (data not shown). Intra-sample coefficient of variation (CV) was used to assess the repeatability of replications within each method. Inter-sample CV was also calculated.

Furthermore, the repeatability coefficient was calculated to quantify the repeatability of each method from replicated measurements obtained by the same method.
The repeatability coefficient ${ }^{16}$ is defined as 1.96 $\sqrt{2^{2} \mathrm{~W}}$ where $\sigma^{2}{ }_{\mathrm{w}}$ is the within subject variance for enzyme activity. Estimation of $\sigma^{2}$ is provided using the mean square error from an ANOVA model with 3 replicates from each sample (sample was the blocking factor for the ANOVA model).

Additionally a plot of the mean difference (i.e., $1^{\text {st }}$ minus $2^{\text {nd }}$ enzyme activity measurement) versus the mean of the two replicate enzyme activity levels was included to graphically summarize the repeatability of each method. The repeatability limits $\left( \pm 2.77 \mathrm{~S}_{\mathrm{w}}\right)$ were added to the graph (as horizontal lines on the $\mathrm{Y}$ axis of Figure $2 b$ ). The mean difference (i.e., mean bias) is not plotted on the graph since the mean difference is statistically zero (as expected). Since the mean bias for the other 2 plots $\left(1^{\text {st }}\right.$ minus the $3^{\text {rd }}$ measurement and $2^{\text {nd }}$ minus the $3^{\text {rd }}$ measurement) were very similar to the first plot these 2 plots were not included in the manuscript.

\section{RESULTS AND DISCUSSION}

Figure 1a represents the estimation of standard NAG (Sigma-Aldrich, St. Louis, USA) by native Reissig et al method $^{1}$ and re-investigated Reissig et al method using $0.8 \mathrm{M}$ and $2 \mathrm{M}$ PTB reagent respectively. The results show no difference in optical activity. The final colored

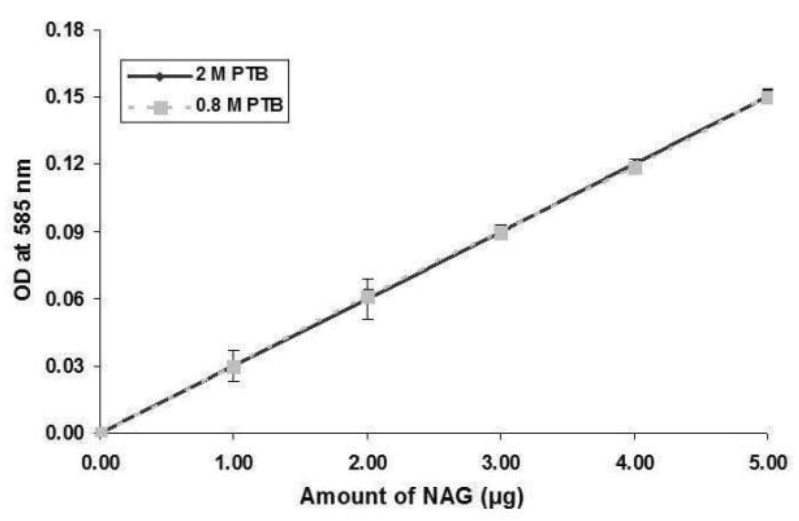

Figure. 1a. Estimation of standard N-acetyl glucoseamine (NAG). The reaction mixture contained different amounts NAG $(0-5 \mu \mathrm{g})$ in $300 \mu \mathrm{l}$ of $0.1 \mathrm{M}$ sodium formate buffer $\mathrm{pH} 3.8$ containing 300 $\mathrm{mM} \mathrm{NaCl}$. The PTB reagent was then added. The sample tubes were heated vigorously in boiling water bath for exactly $3 \mathrm{~min}$ and cooled in tap water, followed by the addition of $1.5 \mathrm{ml}$ of $p$-DMAB reagent. The tubes were maintained at $37^{\circ} \mathrm{C}$ for $20 \mathrm{~min}$ for color development and measured at $585 \mathrm{~nm}$. The PTB reagent, $0.8 \mathrm{M}$ (native) and $2 \mathrm{M}$ (re-investigated) were used and processed according to Reissig et al method [1]. The results were presented as mean \pm SEM of five independent determinations. 


\section{RESEARCH AND REPORTS}

solution was clear with no signs of turbidity and no visible precipitate was observed when centrifuged at $18000 \mathrm{x} \mathrm{g}$ for $10 \mathrm{~min}$ in both the cases. Thus, use of either $0.8 \mathrm{M}$ or $2 \mathrm{M}$ PTB reagent did not affect the intensity of the chromogen generated.

Further, when standard NAG was estimated in presence of serum and plasma samples of varied amounts of proteins $(0$ to $2000 \mu \mathrm{g})$ using native Reissig et $\mathrm{al}^{1}$ method (0.8 M PTB), we observed the formation of turbidity which required centrifugation prior to optical density measurement. When comparing the reinvestigated and native methods using serum protein, at protein $0 \mu \mathrm{g}$, the estimated mean OD at $585 \mathrm{~nm}$ using re-investigated method was $0.150 \mathrm{~nm}$ (95\% CI: 0.147 to 0.153$)$ and at $2000 \mu \mathrm{g}$ protein this value was 0.138 $\mathrm{nm}$ ( $95 \%$ CI: 0.133 to 0.143$)$. In contrast, the estimated mean OD at $585 \mathrm{~nm}$ using native method at protein $0 \mu \mathrm{g}$ and $2000 \mu \mathrm{g}$ were $0.140 \mathrm{~nm}(95 \% \mathrm{CI}$ : 0.137 to 0.144$)$ and $0.043 \mathrm{~nm}(95 \% \mathrm{CI}: 0.040$ to $0.045)$ respectively. The mean OD at $585 \mathrm{~nm}$ of serum of native method was significantly lower than that of reinvestigated method $(\mathrm{p}<0.05)$ at all protein levels (Figure 1b). Analyses of OD at $585 \mathrm{~nm}$ of plasma showed similar results (Figure 1c).

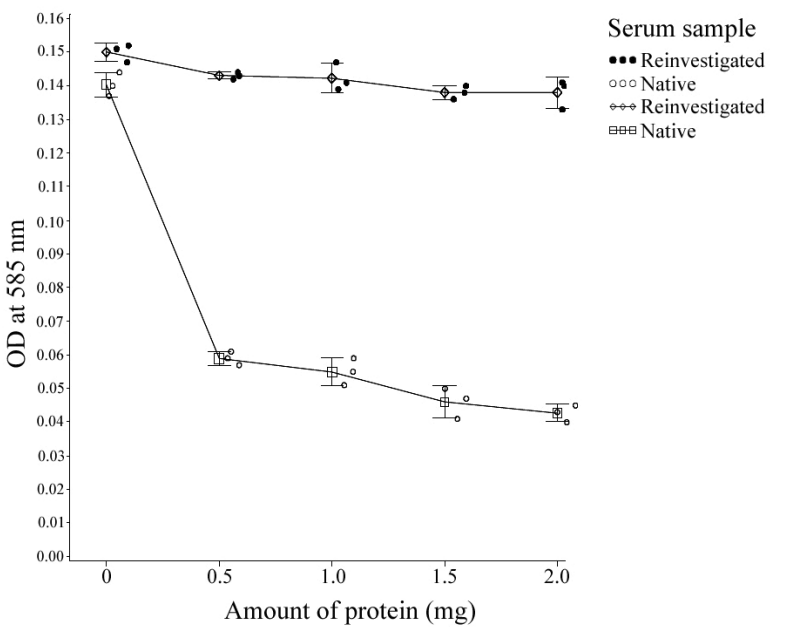

Figure 1b. Estimation of $N$-acetyl glucosamine in the presence of serum proteins. The reaction mixture, $300 \mu \mathrm{l}$ of sodium formate buffer $\mathrm{pH} 3.8(0.1 \mathrm{M}$ with $0.05 \mathrm{M} \mathrm{NaCl})$ containing $5 \mu \mathrm{g}$ each of NAG were added independently with the increasing amounts of total serum protein $(0-2000 \mu \mathrm{g})$. The PTB reagent, $0.8 \mathrm{M}$ (native) and $2 \mathrm{M}$ (re-investigated) were used and processed according to Reissig et al method [1]. The results were presented as mean $\pm 95 \%$ Confidence Interval as well as raw data points.

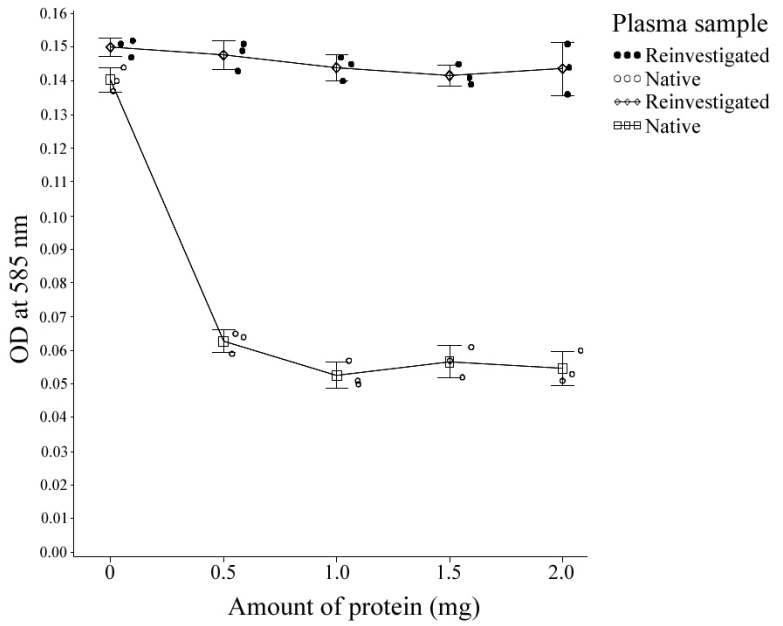

Figure 1c. Estimation of $N$-acetyl glucosamine in the presence of plasma proteins. The reaction mixture, $300 \mu \mathrm{l}$ of sodium formate buffer $\mathrm{pH} 3.8(0.1 \mathrm{M}$ with $0.05 \mathrm{M} \mathrm{NaCl})$ containing $5 \mu \mathrm{g}$ each of NAG were added independently with the increasing amounts of total plasma protein $(0-2000 \mu \mathrm{g})$. The PTB reagent, $0.8 \mathrm{M}$ (native) and $2 \mathrm{M}$ (re-investigated) were used and processed according to Reissig et al method [1]. The results were presented as mean $\pm 95 \%$ Confidence Interval as well as raw data points.

However, when similar estimation was done using $2 \mathrm{M}$ PTB reagent (re-investigated Reissig et al method); no visible turbidity formation was seen. This modification was not only independent of centrifugation but also did not reduce the color intensity (Fig. 1b, 1c). In addition the estimation of NAG in the presence of total serum and plasma proteins and in presence of other protein preparations such as bovine serum albumin, casein and gelatin, the results obtained showed similar trend. The protein content was determined by Biuret method ${ }^{17}$ using bovine serum albumin as standard.

In order to verify this finding, the normal serum HAase activity was estimated. Figure $2 \mathrm{a}$ indicate the independent determination of HAase activity in terms of the end product NAG estimation using $0.8 \mathrm{M}$ (native) and $2 \mathrm{M}$ (re-investigated) $\mathrm{PTB}$ reagent. In presence of 0.8 M PTB, we observed the formation of turbidity as well as reduction in the color intensity. In addition, the color intensity was further reduced when we attempted to obtain clearer supernatant by centrifugation. We observed a drastic reduction in optical density. This poses a serious set back in assessing the actual level of HAase activity in clinical samples. In contrast, when we used $2 \mathrm{M}$ PTB, the samples not only recorded an increased optical density, the samples were 


\section{RESEARCH AND REPORTS}

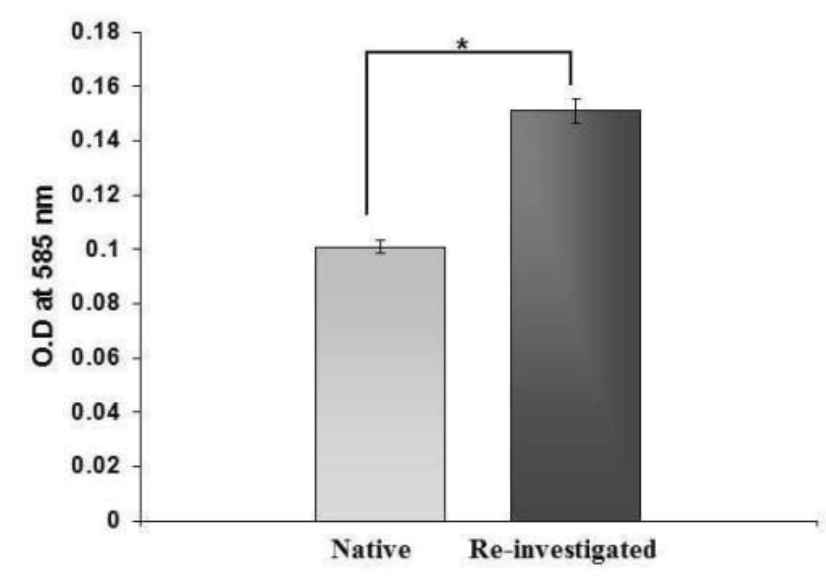

Figure. 2a. Estimation of normal serum HAase activity by the native and the re-investigated Reissig et al methods. The assay mixtures contained buffered substrate solution $(50 \mu \mathrm{g}$ of HA in 300 $\mu \mathrm{l}$ of $0.1 \mathrm{M}$ sodium formate buffer $\mathrm{pH} 3.8$ containing $0.05 \mathrm{M}$ $\mathrm{NaCl}$ ) and normal serum sample (containing $1500 \mu \mathrm{g}$ protein) in a final reaction volume of $300 \mu \mathrm{l}$ and incubated for $150 \mathrm{~min}$ at $37^{\circ} \mathrm{C}$. The reaction was initiated independently by adding the serum samples. The reducing terminal NAG was estimated using native and re-investigated Reissig et al method [1] as described in legend of fig.1a. A difference in normal serum HAase activity between the native and the re-investigated Reissig et al methods was considered statistically significant when $P<0.001{ }^{*}$ ).

clear with no traces of turbidity and no prior centrifugation was required before measuring the optical density. Thus, use of 2 M PTB instead of 0.8 $\mathrm{M}$, ensures clearer solutions even at higher protein levels of clinical samples with the protein content as high as of about $2000 \mu \mathrm{g}$, that is about 5 folds more than that used (about $400 \mu \mathrm{g}$ ) by the native Reissig et al method. ${ }^{1}$ However, further increase in the concentration of $>2 \mathrm{M}$ $\mathrm{PTB}$, did not have any influence on the turbidity nor the intensity of the color formation (data not shown). All the serum samples used for the study were procured by Government Ayurvedic Medical College, Mysore, India with the prior consent from donors.

To access repeatability on the same sample, descriptive statistics of intrasample CV (\%) of normal serum was carried out. The mean intrasample $\mathrm{CV}$ s for native and re-investigated methods were $0.9 \%$ and $0.5 \%$, respectively. On the other hand, the intersample $\mathrm{CV}$ for the native method was $1.7 \%$ while the number was $2.8 \%$ for the re-investigated method. Repeatability coefficient of the native method was estimated as 1.96 $\sqrt{2 S^{2} \mathrm{~W}}=1.96 \sqrt{2(0.000001139)}=0.003 \mathrm{IU}$. In
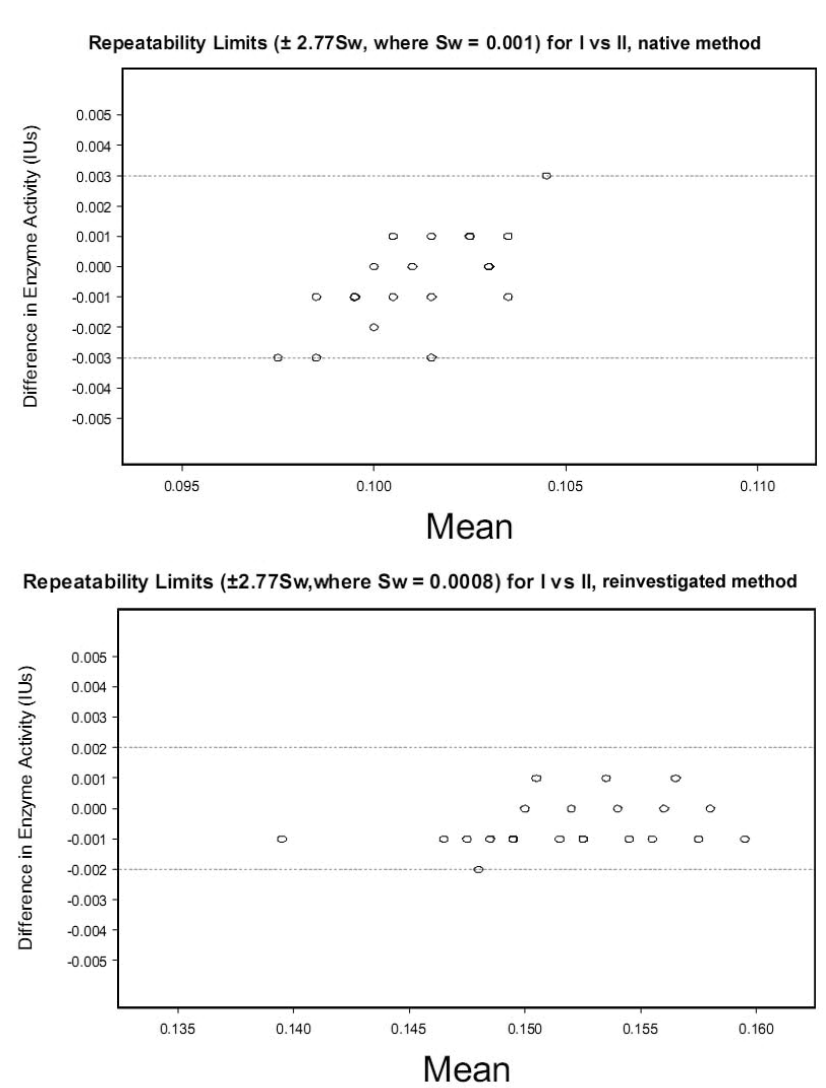

Figure. 2b. Analysis of normal serum HAase activity by the native and the re-investigated Reissig et al methods. Limits of Repeatability: The mean difference (i.e., $1^{\text {st }}$ minus $2^{\text {nd }}$ enzyme activity measurement) was plotted versus the mean of the two replicate enzyme activity levels. The repeatability limits $\left( \pm 2.77 S_{\mathrm{w}}\right)$ were added to the graph.

other words, $0.003 \mathrm{IU}$ was the difference that would be exceeded by only $5 \%$ of pairs of measurements made by the native method on the same subject. Re-investigated method's repeatability coefficient was estimated as 1.96 $\sqrt{2 S^{2} \mathrm{~W}}=1.96 \sqrt{2(0.000000627)}=0.002$ IU. In other words, $0.002 \mathrm{IU}$ was the difference that would be exceeded by only $5 \%$ of pairs of measurements made by the native method on the same subject. Figure $2 \mathrm{~b}$ shows the repeatability limits of re-investigated $( \pm 0.003 \mathrm{IU})$ and native methods ( $\pm 0.002 \mathrm{IU})$ for normal serum. No $1^{\text {st }}$ minus $2^{\text {nd }}$ enzyme activity measurements exceeded the repeatability limits for both methods.

In conclusion, the estimation of HAase activity in clinical samples appears to be tedious and results in anomaly. This is due to turbidity interference when higher protein concentrations $(>400 \mu \mathrm{g})$ are used. Also 


\section{RESEARCH AND REPORTS}

there is, the fact that underscores is the difficulty in obtaining the measurable activity with lower protein concentrations in samples. The re-investigated method we have tested and are proposing a satisfactory and effective means of determining the HAase activity even when high proteins are present in clinical samples. The reaction mixtures were not turbid but clear, permitting a more accurate estimation of the activity of the enzyme in clinical samples.

\section{ACKNOWLEDGEMENT}

The authors thank Prof. Vasanth D Bhat, Regional Institute of Education, Govt. of India, Mysore for his valuable suggestions during the study. The authors are also thankful to Dr. Mangalgi and Dr. Aruna Mangalgi, Department of Kayachikitsa, Govt. Ayurvedic Medical College, Mysore for providing serum samples. Dr. S. Nagaraju thanks the Council of Scientific and Industrial Research (CSIR), New Delhi, India for financial assistance.

\section{REFERENCES}

1. Reissig JL, Stronminger JL, Leloir LF. A modified colorimetric method for the estimation of $\mathrm{N}$-acetyl glucosamine sugars, J Biol. Chem.1955;217:959-66.

2. Stern R, Jedrzejas MJ, Hyaluronidase: their genomics, structures and mechanisms of action, Chem Rev. 2006;106:818-39.

3. Nagaraju S, Devaraja S, Kemparaju K. Purification and properties of hyaluronidase from Hippasa partita (funnel web spider) venom. Toxicon 2007:383-93.

4. Nagaraju S, Mahadeswaraswamy YH, Girish KS, Kemparaju K. Venom from spiders of genus Hippasa: Biochemical and pharmacological studies. Comp Biochem Physiol-C 2006;1444:1-9.

5. Girish KS, Kemparaju K. The magic glue hyaluronan and its eraser hyaluronidase: A biological review, Life Sci. 2007;80:1921-43.

6. Meyer K. Hyaluronidases. In: Boyer, P.D. (Ed.), The enzymes. Academic press New York, 1971.

7. Kreil G, Hyaluronidases- a group of neglected enzymes, Protein Sci. 1995;4:1666-9.

8. Kemparaju K, Girish KS. Snake venom hyaluronidase: a therapeutic target, Cell Biochem. Funct. 2006;24:7-12.

9. Frost GI, Csoka T, Stern R. The hyaluronidases: a chemical, biological and clinical overview, Trend Glycosci. Glycotech. 1996;8:419-34.

10. Jedrzejas MJ, Stern R. Structures of vertebrate hyaluronidases and their unique enzymatic mechanism of hydrolysis, Proteins Stru Func Bioinform. 2005;61:227-38.

11. Csoka TB, Frost GI, Stern R. Hyaluronidase in tissue invasion, Invasion metastasis. 1997;17:297-311.

12. Stern M, Stern R. An ELISA- like assay for hyaluronidase and hyaluronidase inhibitors, Matrix. 1992:12;397.

13. Takahashi T, Kawai MI, Okunda R, Suzuki K. A flurometric Morgan-Elson assay method for hyaluronidase activity, Anal. Biochem. 2003;322:257-63.

14. Elson LA, Morgan WT. A colorimetric method for the determination of glucosamine and chondrosamine, Biochem. J. 1933;27:1824-8.

15. Asteriou A, Deschrevel B, Delpech B, Berlrand P, Bultelle F, Merai C, et al. An improved assay for the $\mathrm{N}$-acetyl glucosamine reducing ends of polysaccharides in the presence of proteins, Anal. Biochem. 2001;293:53-9.

16. Bland JM, Altman DG. Measuring agreement in method comparison studies. StatisticalMethods in Medical Research. 1999;8:136-60.

17. Wokes F, Still BM. The estimation of protein by the biuret and Greenberg methods, Biochem. J. 1942;36;797-806.

\section{Member Renewal} Thank You!

$>$ ASCLS wants to THANK YOU for renewing your membership for the 2010-2011 year!

> ASCLS is offering 6 online quizzes at no charge to help with your CE needs.

$>$ For details* about this offer and order form, go to www.ascls.org/education/memberthankyou .

$>$ We know you have choices as to which organization you belong and we are thrilled you chose ASCLS!

*For PF1, PF2, \& FYP members who renewed by $9 / 30 / 10$

*Must complete quizzes by $7 / 31 / 11$ 